\title{
Impact of flood hazard on settlement distribution pattern on active flood plains of CHEJ interfluves Punjab Pakistan (1951- 1998)
}

\author{
Sajid Mahmood Farooqi ${ }^{1}$, Prof. Dr AzraParveen Azad ${ }^{2}$ \\ 1: Assistant Prof of Geography, Govt. College Asghar Mall Rawalpindi. Ph.D. Scholar UOK, Karachi \\ 2: Department of Geography, UOK, Karachi
}

\begin{abstract}
Analysis of the spatial patterns of natural and human phenomena makes the core of geographical researches possess both academic and practical values. Research in the pattern of settlement distribution is one such study analysing the point distribution patterns. In this paper, an effort has been made to study the settlement distribution pattern and the factors influencing and controlling such distribution and growth of settlement on the CHEJ interfluve in general, and on the Active Flood Plains (AFP) in particular.
\end{abstract}

Key Words: Settlement Distribution Pattern, CHEJinterfluve, Active Flood Plains

\section{Introduction:}

Study of the distribution of human and physical phenomena and research in finding the organisation or pattern in that distribution has the manifest objective of finding relationship between the given distribution and the controlling factors. Such relationships help in predicting the pattern of distribution of that phenomenon for future and in some cases, planning the distribution of some geographic phenomenon. Among the geographic distributions some are continuous in the sense that they continually vary over space. Temperature, pressure, elevation, etc. are examples of such distributions. Some distributions though not continuous in the strict sense are practically continuously distributed in the real world. Population density, crop yield, etc. are included in such distributions and are treated as continuous. Contrary to such distributions is a discrete distribution which does not vary continuously over space. Every observation which may be a line, a point or an area phenomenon has its own peculiar location estranged from others by some space. These are not contiguous to each other and even if some of them are contiguous these are treated as separate and discrete geographic entity. Cities, settlements, schools, hospitals, nodes on transportation network, wells, land-use parcels, etc. are discrete phenomenon ${ }^{[1]}$. Such distributions are categorised as such because different quantitative and cartographic techniques are required to find out the patterns and analyse such distributions.

Discrete point distribution in a region may be taken as dots on patches, dots being the phenomenon to be represented as points and patch being the area or region in which such point distribution phenomenon exists $^{[2]}$. Settlement distribution in a region is a discrete point distribution; study of settlement distribution has both theoretical and practical importance. Theories related to the pattern of point distribution may be tested verified and if necessary modified or new theories may be formulated.

Two different approaches i.e. theoretical and ideographic can be adopted to analyse the nature and pattern of human settlement processes and distributions ${ }^{[3]}$. In theoretical approach patterns are analysed in a theoretical framework. Some already formulated theory or model, proved successful in other areas may be applied to analyse the distribution pattern in study area. This normative approach is considered more scientific than other approaches ${ }^{[4]}$. The second approach to research is ideographic in which our main emphasis is not on generalizing the result, but to study each phenomenon as a unique one. But it does not prevent some generalization being made about the factors influencing the patterns. The impact of local conditions and the historical events is also important in this connection. In some cases human settlement distribution pattern may be affected by one powerful influence at a particular period of time. In this particular study the ideographic approach is adopted to find out the impact of floods on settlement distribution pattern, taking that it may prove helpful in determining the factors which control the location of settlements and hence the distribution of those settlements. Such distribution studies may be useful in predictingthe patterns in future and may be helpful in regional planning of the settlements. Present study mainly focuses on the settlement distribution pattern on the most prominent hazard prone areas of Pakistan "the active flood plains", which in most summers are inundated regularly year after year and are still inhabited by millions and without any planning.

Human occupation of flood prone areas has an ancient history starting from the time when untamed rivers furiously ravaged all life and property that dare impede its path. Flood plains, a product of river deposition,are considered to be the most fertile land for agriculture and thus stimulate the humans for abode. 
The human civilization started and evolved on the river banks,Mesopotamia, Indus and Nile civilisations are the perfect forensicevidence ${ }^{[5]}$. Today a large proportion of the human population is dwelling on the active flood plains under the continuous threat of inundation and complete obliteration; especially in the developing countries the situation is more alarming. It gets exacerbated due to population explosion and lack of required infrastructure to absorb this increased pressure on their available resources.Consequently the marginalized and under-privileged sections of society are forced to take refuge in the hazard prone areas for livelihood and dwellings. These economically and socially neglected segments of society have intuited themselves with the strategies to compete and cope with the eventualities. Their only available panacea is either accepting the losses or adjusting with the emerging situations.

Pakistan is a densely populated country of 181.9 million (132 million in 1998) people with an average annual growth rate of 2.69. Out of this population 73.621 million (1998) resides in the province of Punjab of which approximately $68.73 \%$ is ruralpopulation ${ }^{[6]}$. Punjab - the land of five rivers, the same rivers that provide an identity to this geographical administrative unit of Pakistan. Theword "Punjab" has been coined from the Persian words 'Punj' meaning five and 'ab' is used for water in Persian so the complete meaning of the word "Punjab"is the land of five rivers although the historical and geological evidences suggest that there were actually seven instead of five rivers running in the present day territorial boundaries of Punjab ${ }^{[7]}$.

Most of the area of Punjab is spread over4 interfluves,SindSagar Interfluve lies between the River Sind and River Jhelum, CHEJ Interfluve between River Jhelum and River Chenab, RACHNA Interfluve between River Chenab and River Ravi, BARI Interfluve between River Ravi and River Bias. Among these interfluves CHEJ has been chosen as study area as it had witnessed some of the historical floods in the history of Pakistan damaging hundreds of settlements and thousands of lives implicating irreparable social and economic damages, yet densely populated and agriculturally and economically more prosperous.

\section{The Study Area}

The CHEJ interfluve is the Northern smallest and agriculturally most prosperous area of Punjab. The interfluve comprising (2823500 Acers) $11426 \mathrm{Km}^{2}$ is bounded by River Jhelum on the Northwest and River Chenab on the Southeast; CHEJ is the contraction of Chenab and Jhelum. ${ }^{[8]}$

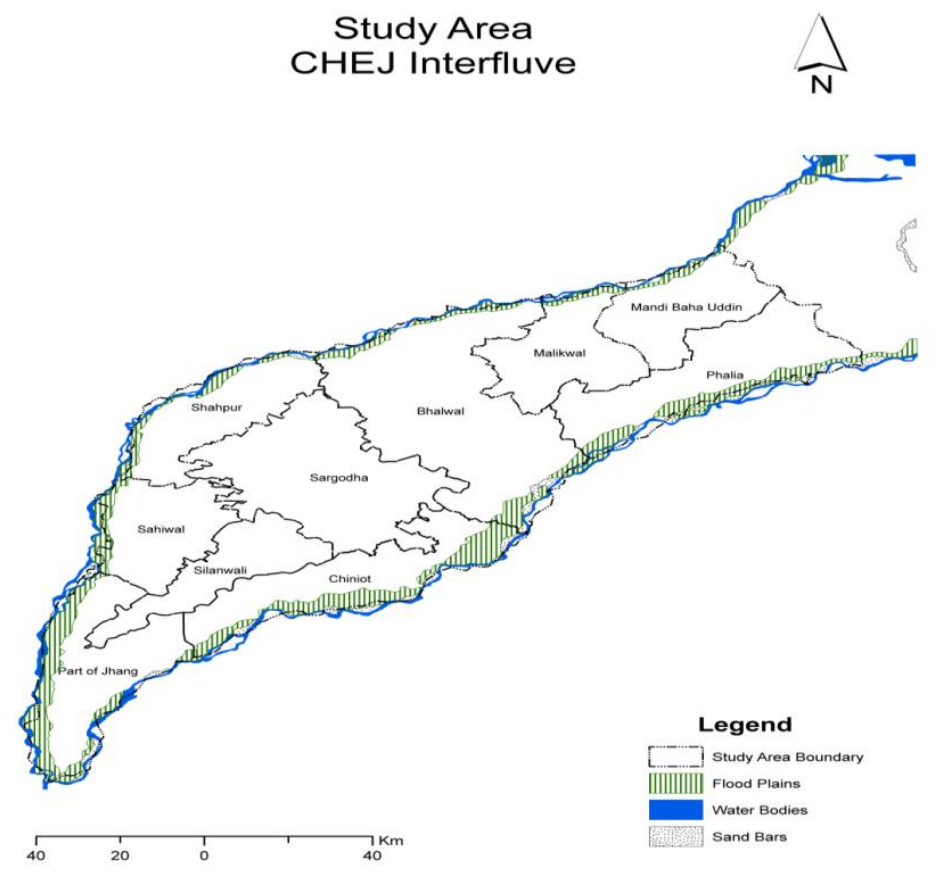

Active flood plains are the lands just adjacent to the rivers thatinundate during most of the summers. These flood plains are composed of young alluvium, deposited by floodsevery summer, thus soils are free of salinity and supposed to be very fertile. CHEJ interfluve contains (289500 Acers) $1172 \mathrm{Km}^{2}$ of active flood plains which is about $10.25 \%$ of the total area of the interfluves ${ }^{[9]}$. The nature and character of flood plains of Jhelum River and the River Chenab is different from each other reason being the different timing, nature and character of floods of both the rivers. In river Jhelum,most of the floods occur during the months of July and August because of heavy rainfall during the monsoon months in the catchment areas, only a few floods occur in the month of September. Snowmelt runoff contributes very little as it occurs from February reaching a peak in 
$\operatorname{March}^{[10]}$. After the completion of Mangla Reservoir in 1967, the severity of Jhelum flood has greatly reduced. Heavy floods in river Chenab occur mostly in the months of September and August; snowmelt runoff contributes about $40 \%$ of the total flow on theaverage in the month of July ${ }^{[11]}$. The active flood plains of River Jhelum from downstream Rasul to its junction with River Chenab at Trimmun Headwork is about 150,000 Acers of very fertile soil. The active flood plains of River Chenab comprisean area of 138,500 Acers ${ }^{[12]}$ of land which is constituted of relatively coarse material not so fertile and less extensively cultivated compared to AFPs of River Jhelum.

The study area is spread over the districts of Mandi Bahauddin, Sargodha, and parts of District Jhang.

\section{Materials and Methods}

To conduct this research, descriptive, cartographic and quantitative methods have been used. The settlement distribution pattern was mainly determined by using the nearest neighbour index, layer overlay techniques aided by statistical methods and GIS.

An analysis of natural factors thought to be influencing the settlement distribution was also made, revealing a varying degree of controls on the distribution pattern. Among these natural factors taking floods, the major actor supposed to be affecting the distribution pattern on the AFPs, the study area was divided into three parts namely Up Streams, Mid Streams and Down Stream reaches,based on the assumption that nature and magnitude of floods changes going down streams, hence affecting the distribution pattern differently on different parts of the active flood plains. Another fact that the severity of the floods decreases with increasing distance from the river bank, the study area was also divided into strips of identical width and the supposed impact of severity of the floods on the distribution pattern was also evaluated. To support the idea that floods may have a profound impact on the settlement distribution patternthe growth rate parameter of the settlementshas also been analysed between different census periods.

To carry out the research base map of the study area was adopted from the Colombo Plan Cooperative Project Report, 1958," Landforms, Soils and Land Use of the Indus Plains West Pakistan". The then extent of Active flood plains of both the rivers in question was marked from the base map, this map was than overlaid on the topographic maps of the concerned area and settlements were marked as points. Further analysis was carried out for the point distribution pattern, taking settlements as points.

\section{Results and Discussions}

The active flood plains of River Jhelum and Chenab River contain a number of settlements of different sizes growing in space and time despite the regular annual occurrence of floods, of which some were of historic nature in terms of magnitude, incurring severe damages of tangible (property and crop), and intangible (life losses) nature. 89 settlements on the AFP of Chenab and 116 on the Jhelum AFP were identified as the objects under study.

The study to establish any orderin spacing of settlements by comparing the actual settlement distribution pattern in space with a hypothetical random pattern, the straight-line distance from each settlement to its nearest neighbor is measured and this is divided by the total number of settlements to give the observed mean distance between nearest neighbors ${ }^{[13]}$

The density of points is calculated as:

Number of points in the study

Size of the study area

The expected mean in a random distribution is calculated as: 1

$\overline{2 \sqrt{\text { density }}}$

The expected mean is compared with the observed mean.

$$
\begin{gathered}
\mathrm{Rn}=\frac{\text { Observed Mean }}{\text { Expected Mean }} \\
\mathrm{Rn}=\frac{\mathrm{D}(\mathrm{Obs})}{\frac{1}{2} \sqrt{\mathrm{a}} / \mathrm{n}}
\end{gathered}
$$

$\mathrm{Rn}$

nearest neighbor value

$\mathrm{D}(\mathrm{Obs})$

mean observed nearest neighbor distance 
An index of zero indicates a completely clustered situation. 1 shows a random pattern, 2 a uniform grid, and 2.5 a uniform triangular pattern. The interpretation of index values can be difficult since these values are not part of a continuum.

Nearest Neighbour Index was applied to find out the general settlement distribution pattern in the study area. Attempts were made to ascertain whether this pattern evolved under the influence of a single factor like risk of flood inundation or a multiplicity of factors contributed.Some observations using the nearest neighbour index are as follows:

Nearest Neighbour Index for the settlements on both the active flood plains reveal that AFP of Jhelum River has an index value of 1.08 and the AFP of Chenab River is 0.8. Both the values being very close to 1 show a tendency of random distribution as a whole. Statistically it might be true but on the ground certain other variables (environmental controls like floods and climatic setting in this case) other than distance between the nearest neighbours might also be operating, which may have their effect on the distribution pattern.

(Assumption 1) Diminishing impact of floods with increasing distance from river:

Assuming that the severity of flood decreases with the increasing distance from the river, active flood plains of both the rivers has been divided into four parallel $1 \mathrm{Km}$ wide strips.

\begin{tabular}{|c|c|c|c|c|c|c|c|c|c|c|}
\hline \multirow{3}{*}{ 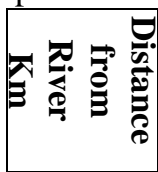 } & \multicolumn{5}{|c|}{ River Jhelum (.19 settlements / $\mathrm{Km}^{2}$ ) } & \multicolumn{5}{|c|}{ River Chenab (.16 settlements / Km²) } \\
\hline & \multicolumn{2}{|c|}{ Area } & \multirow{2}{*}{$\begin{array}{l}\% \text { of } \\
\text { Area }\end{array}$} & \multirow{2}{*}{$\begin{array}{l}\text { No. of } \\
\text { Settlem } \\
\text { ents }\end{array}$} & \multirow{2}{*}{$\begin{array}{l}\text { Density } \\
\text { Sett/Km } \\
2\end{array}$} & \multicolumn{2}{|c|}{ Area } & \multirow{2}{*}{$\begin{array}{l}\% \text { of } \\
\text { Area }\end{array}$} & \multirow{2}{*}{$\begin{array}{c}\text { No. of } \\
\text { Settlem } \\
\text { ents }\end{array}$} & \multirow{2}{*}{$\begin{array}{l}\text { Density } \\
\text { Sett/Km } \\
2\end{array}$} \\
\hline & Acer & $\mathrm{Km}^{2}$ & & & & Acer & $\mathrm{Km}^{2}$ & & & \\
\hline$>1$ & 58500 & $\begin{array}{c}236.7 \\
4\end{array}$ & $39 \%$ & 38 & .16 & 54015 & 218.59 & $39 \%$ & 29 & .13 \\
\hline $1-1.99$ & 36000 & $\begin{array}{c}145.6 \\
9\end{array}$ & $24 \%$ & 43 & .30 & 34625 & 140.11 & $25 \%$ & 28 & .20 \\
\hline $2-2.99$ & 30000 & $\begin{array}{c}121.4 \\
1\end{array}$ & $20 \%$ & 23 & .19 & 27700 & 112.10 & $20 \%$ & 11 & .09 \\
\hline$<3$ & 25500 & $\begin{array}{c}103.1 \\
9\end{array}$ & $17 \%$ & 12 & .12 & 22160 & 90.00 & $16 \%$ & 21 & .23 \\
\hline Total & $\begin{array}{c}150,00 \\
0\end{array}$ & $\begin{array}{c}607.0 \\
3\end{array}$ & $\begin{array}{c}100 \\
\%\end{array}$ & 116 & & $\begin{array}{c}138,50 \\
0\end{array}$ & 560.81 & $100 \%$ & 89 & \\
\hline
\end{tabular}

Active flood plains of River Jhelum host 116 settlements over an area of 607.03 square kilometres with a settlement density of .19 settlements / $\mathrm{Km}^{2}$. There are 89 settlement on active flood plains of river Chenab spread over an area of 560.81 square kilometreswith a settlement density of .16 settlements / $\mathrm{Km}^{2}$. Comparison of both theAFPs reveal almost similar results with slight differences. On both the active flood plains there is a tendency of insignificant crowding away from the river. The first strip of both the AFPs covers the highest proportion of the area with less number of settlements and density even less than the overall settlement density of the respective AFP. The second strip shows a crowding of settlements on a comparatively lesser area along both the rivers, the third strip of the Chenab active flood plain shows a strange behaviour with a settlement density of .09 settlements / $\mathrm{Km}^{2}$, which obviously is not due to floods but the land use. This strip of Chenab active flood plain is scrub and a wasteland unsuitable for cultivation and hence settlement. The case of the outermost strip of Jhelum active floodplain is similar to the third strip of Chenab AFP with apparently different reasons. Here the settlements seemed to shift over to meander flood plains because less of the land is available on AFP compared to the adjacent hazard free meander flood plain.

\section{(Assumption 2) Change in the nature and magnitude of floods going downstream:}

Another assumption in this study was that nature and magnitude of floods changes going down stream. This may have an impact on the settlement distribution pattern. To analyse this assumptionthe study area has been divided in to the Upstream, Midstream and Downstream reaches. Basis of this assumption is that people in the upper reaches get less time to respond to the flood warning hence cannot properly adjust to the situation. On the other hand dwellers of the lower reaches have sufficient time to respond and adjust to the situation, despite the fact that the magnitude of flood waters is much greater in these areas. 
Impact of flood hazard on settlement distribution pattern on active flood plains of CHEJ interfluves

\begin{tabular}{|c|c|c|c|c|c|c|c|c|}
\hline \multirow{2}{*}{$\begin{array}{c}\text { AFP Reaches } \\
\text { along the river }\end{array}$} & \multicolumn{4}{|c|}{ River Jhelum } & \multicolumn{4}{c|}{ River Chenab } \\
\cline { 2 - 9 } & $\begin{array}{c}\text { Area } \\
\left(\mathbf{K m}^{2}\right)\end{array}$ & $\begin{array}{c}\text { \% of } \\
\text { AFP }\end{array}$ & $\begin{array}{c}\text { No. of } \\
\text { Sett. }\end{array}$ & $\begin{array}{c}\text { Sett. } \\
\text { Density }\end{array}$ & $\begin{array}{c}\text { Area } \\
\left(\mathbf{K m}^{2}\right)\end{array}$ & $\begin{array}{c}\text { \% of } \\
\text { AFP }\end{array}$ & $\begin{array}{c}\text { No. of } \\
\text { Sett. }\end{array}$ & $\begin{array}{c}\text { Sett. } \\
\text { Density }\end{array}$ \\
\hline $\begin{array}{c}\text { Upstream } \\
\left(32^{\circ} 20^{\prime}-33^{\circ} \mathrm{N}\right)\end{array}$ & 224.61 & $37 \%$ & 42 & .19 & 84.57 & $15 \%$ & 4 & .05 \\
\hline $\begin{array}{c}\text { Midstream } \\
\left(31^{\circ} 40^{\prime}-32^{\circ} 20 \mathrm{~N}\right)\end{array}$ & 188.17 & $31 \%$ & 42 & .22 & 381.14 & $68 \%$ & 75 & .20 \\
\hline $\begin{array}{c}\text { Downstream } \\
\left(31^{\circ}--31^{\circ} 40^{\circ} \mathrm{N}\right)\end{array}$ & 194.25 & $32 \%$ & 32 & .16 & 95.20 & $17 \%$ & 10 & .11 \\
\hline TOTLAL $^{-6}$ & 607.03 & $100 \%$ & 116 & & 560.81 & $100 \%$ & 89 & \\
\hline
\end{tabular}

This approach seems more meaningful on the active flood plains of River Jhelum, as the area of this AFP is more evenly distributed among the three reaches with little variations in settlement distribution. The upstream area is comparatively less populated with .19 settlements $/ \mathrm{Km}^{2}$ spread over a larger proportion $(37 \%)$ of the area of AFP. The midstream area along River Jhelum has the same number of settlements as that of the upstream reach but on a smaller proportion $(31 \%)$ of the area of AFP. This part of active flood plain of Jhelum River shows a little crowding of the settlements. The downstream reaches of AFP of Jhelum is least populated with .16 settlements $/ \mathrm{Km}^{2}$. This part of the flood plain is low lying; topographically flat and situated just above the confluence of River Jhelum and Chenab. The maximum volume of the floodwaters is recorded in this zone, which remains in the area for longer times. At the same time the irrigation network of the CHEJ interfluve terminates here discharging the excess water from the system back into the rivers therefore the land use of this area is mostly marshy wastelands and riverine forests leaving less room for settlements.

The active flood plains of Chenab River exhibit a strange setting; here the midstream reach of AFP occupies $68 \%$ of the total area of the active flood plains, more than double the area of up and downstream reaches cumulatively. The conditions of the downstream reach of the Chenab AFP are identical to those of the downstream reach of Jhelum AFP. Along the River Chenab configuration of the AFP and land use pattern are more powerful and direct controls affecting the settlement distribution pattern, whereas impact of floods is weak and indirect

\section{(Assumption 3) Climatic Regions and Settlement Distribution:}

Favourable climates favour the growth of settlements, therefore, the regions of the world with favourable climates have greater concentration of settlements. Harsh climatic regions like deserts and mountainous areas have lower concentration of settlements. These facts depict that Climate is another factor responsible for growth and distribution of settlements. According to Köppen's classification of climates,Pakistan is situated in the B type or arid climates (average annual rainfall less than 10") in the global setting of climates ${ }^{[14]}$. The study area is located in a typical arid region. In this region, temperature increases downstream or Southwards and rainfall decreases. The study area is further divided into four climatic zones in the regional climate setting. ${ }^{[15]}$

1. Sub HumidSub-montane North:Lies between 40" isohyet in North and 20" isohyet in South with a higher range of temperature. The Mean Maximum for June is $105^{\circ} \mathrm{F}$ and Mean Minimum for January is $42.2^{\circ} \mathrm{F}$.

2. Semi-Arid Plains of Central Punjab (a): Lies between the $20^{\prime}$ isohyet in the North and $15^{\prime}$ isohyet in the South with profound summer rainfall and a high range of temperature.

3. Semi-Arid Plains of Central Punjab (b): Lies between the 15" isohyet in the North and 10" isohyet in the South. Rainfall is slightly less than its Northern counterpart and a high range of temperature.

4. Arid Central Irrigated Plains: Lies South of 10" isohyet with very hot summers and mild winter, exhibits trudesert conditions cultivation is practiced with the help of irrigation. 

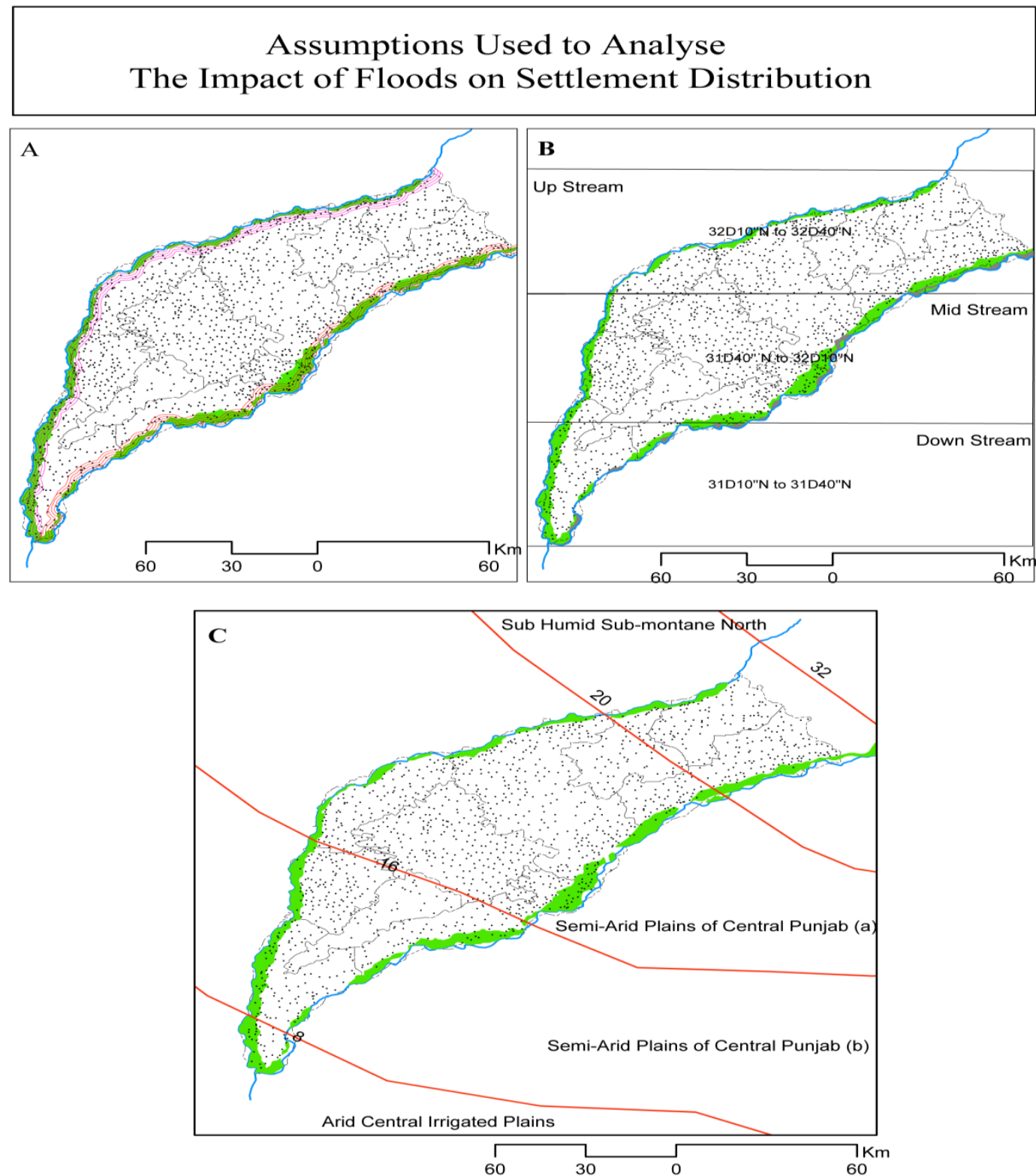

In the study area, all of the settlements are situated in the three Southern climate zones. Maximum number of settlements is in the Semi-Arid Plains of central Punjab, where a very dense network of irrigation channels crisscross the area and agriculture is the main economic activity. The Southernmost part of the study area has a very low concentration of settlements with higher growth rates on the AFP of River Jhelum and lower growth rates on AFP of Chenab River. On the active flood plain of River Jhelum, growth rates increase southwards and the harshness of climates is compensated by a better land use pattern. On the AFP of Chenab River the control of climatic conditions is much stronger which is even reflected in the land use pattern, therefore harsh climates combined with poor land use pattern are the main reasons of decreasing growth rates.

\section{Conclusion}

Settlements are a product of favourable environment and time or history. Where site, situation, and location are important factors of evolution, growth, and distribution of settlements, the time, or history of the settlement also plays an important role. Settlements of the area under study have been in the same site and situation for centuries with dwellers living under a continuous threat of annual flooding of different intensities and resultant losses of life and property. Floods of low and medium intensity are a common phenomenon but exceptionally high floods also occur in these areas destroying settlements of all sizes and inflicting heavy life and property losses. Having no other choice but to live in the hazard prone area, under an annual threat of inundation, has left deep impacts on the everyday life of the dwellers of the Active Flood Plains.

A very few settlements were found relocated a few hundred meters away from the river by the residents but not out of the hazard zone. Majority of the settlements have persisted at the same place from the day of their 
origin but only on raised foundations. This behaviour of the settlements and the dwellers is evident from the growth pattern of the settlements. The growth rate analysis revealed that settlements situated away from the river and in downstream reaches have higher growth rates compared to the settlements in the close vicinity of the river and in the upper reaches of the active flood plains.

It can be concluded from this study that environmental controls affect both directly and indirectly the distribution pattern of settlements, whereas the growth pattern is under a much more complex control of environmental, economic, cultural and traditional factors.

\section{References:}

[1]. R. Hammond \&P. McCullough.1978. "Quantitative Techniques in Geography: An Introduction”.Clarendan Press, Oxford. P.3, 49$59,79-85$.

[2]. J. P. Cole \& C. A. M King 1968. "Quantitative Geography". Jhon Willey and Sons, London, P.10

[3]. Ackerman Edward A.1958." Geography as a fundamental research discipline”. University of Chicago.

[4]. Gupta S. 1993. " Research methodology and Statistical Techniques". Deep \& Deep Publications F-159, Rajouri Garden New Delhi, P. 70-72

[5]. http://www.census.gov.pk/AreaDensity.htm

[6]. Burn, R. (1908). THE IMPERIAL GAZETTEER OF INDIA. Journal of the Royal Society of Arts. P. 30, Retrieved from http://onlinelibrary.wiley.com/doi/10.1002/cbdv.200490137/abstract

[7]. Fraser, I. S. (1958), "Landforms, Soils and Land Use of Indus Plains West Pakistan". A Colombo Plan Co-Operative Project Report Published by Government of Canada for the Government of Pakistan. (P. 247, table: 34)

[8]. Fraser, I. S. (1958), "Landforms, Soils and Land Use of Indus Plains West Pakistan". A Colombo Plan Co-Operative Project Report Published by Government of Canada for the Government of Pakistan. (P. 247, table: 34)

[9]. Afzal M. (1994). "Pakistan Flood Management Procedures Including 1992 Super Flood and its Damage Restoration". Water Resource Management Directorate WAPDA, Lahore, W.R.M Publication No. 294. December 1994. P. 3.

[10]. Awan, S. A. 2003. "Pakistan: Flood Management - River Chenab From Marala ToKhanki-Integrated Flood Management Case Study".WMO/GWP Associated Programme on Flood Management 2003. P. 4. Retrieved from http://www.apfm.info/pdf/case_studies/cs_pakistan_chenab.pdf

[11]. Fraser, I. S. (1958), "Landforms, Soils and Land Use of Indus Plains West Pakistan". A Colombo Plan Co-Operative Project Report Published by Government of Canada for the Government of Pakistan (P. 248, table: 35)

[12]. Fraser, I. S. (1958), "Landforms, Soils and Land Use of Indus Plains West Pakistan". A Colombo Plan Co-Operative Project Report Published by Government of Canada for the Government of Pakistan (P. 248, table: 35)

[13]. Azad, A \& Mahmood, K., "AGeographical Investigation of Rural Settlements in Rawalpindi District", Pakistan Journal of Geography, Vol. XII \& XIII, Nos. 1\&2, June-Dec, 2003-2004

[14]. http://en.wikipedia.org/wiki/File:NorthIndiaClimateKoppen.png

[15]. Ahmed. K. S. (1951),"Climatic Regions of West Pakistan". Pakistan Geographical Review, Vol. VI, No.I PP 1-35 